\title{
The Field of Fields. The State According to Pierre Bourdieu
}

\author{
Francisco Villacorta Baños \\ Instituto de Historia, CSIC, calle Albasanz, 26-28, 28037, Madrid (Spain) \\ e-mail: francisco.villacorta@cchs.csic.es \\ ORCID id: http://orcid.org/0000-0002-7481-3894
}

\begin{abstract}
Submitted: 13 December 2016. Accepted: 12 January 2017
ABSTRACT: A book published in 2012 included the publication of the lecture course on the State delivered by Pierre Bourdieu at the Collège de France. The course was given at a time when Bourdieu's work had reached full maturity, and it completed, at the most generic level of significance - in the "geometral of all perspectives" - the analytical potential opened up by the main categories he used to approach the social world: habitus, field and, above all, capital or symbolic power, the true core of uncontested legitimacy and of the omnipresent domination that the state has acquired in the contemporary world.
\end{abstract}

KEYWORDS: State; Pierre Bourdieu; Generative or Genetic Structuralism; Symbolic Capital; Symbolic Power; Habitus; Social Field.

Citation / Cómo citar este artículo: Villacorta Baños, Francisco (2017) "The Field of Fields. The State According to Pierre Bourdieu". Culture \& History Digital Journal, 6 (1): e010. doi: http://dx.doi.org/10.3989/chdj.2017.010.

RESUMEN: El campo de los campos. El Estado según Pierre Bourdieu.- Un libro publicado en 2012 recoge el curso oral impartido por Pierre Bourdieu en el Collège de France acerca del Estado. Emplazado en una etapa ya de plena madurez del sociólogo francés, el curso remata en el nivel de significación más genérico -en el plano geométrico ("géometral") de todas las perspectivas- las potencialidades analíticas abiertas por sus principales categorías de enfoque del mundo social: el habitus, el campo y, sobre todo, el capital o poder simbólico, el auténtico núcleo de la legitimidad incontestada y del dominio omnipresente que ha llegado a adquirir el Estado en el mundo contemporáneo.

PALABRAS CLAVE: Estado; Pierre Bourdieu; Estructuralismo Genético; Capital Simbólico; Poder Simbólico; Habitus; Campo Social.

Copyright: (C) 2017 CSIC. This is an open-access article distributed under the terms of the Creative Commons Attribution License (CC BY) Spain 3.0.

\section{A GENERAL BOOK OF KEY CONCEPTS}

During 1990 and 1991 the French sociologist Pierre Bourdieu (1930-2002) devoted his lecture course in the Collège de France to the analysis of the State. The lecture was published in 2012 under the editorial responsibility of his disciples Patrick Champagne, Remi Lenoir, Franck Poupeau and Marie-Christine Rivière (Bourdieu, 2012). Given the theme of the book, the pedagogic role of the transcribed lecture, and its two temporalities (that of the course delivery and that of its publication, a decade after the death of its author), a set of circumstances are brought together within it that directly interpellate some of the key concepts in the intellectual enterprise and currency of the French sociologist (Lenoir, 2012).

Firstly, the course was delivered in a period when Bourdieu's academic activity had matured, after having strongly established the foundations of his peculiar sociological undertaking drawn from his field studies, first in Algeria and later in the French rural world, through his surveys on cultural consumption, and the functioning of some state institutions of vital importance in social reproduction, such as education. The theoretical reflections based on these foundations had already then become em- 
bodied in solid analytical categories, especially the concepts of "habitus" and "field". They were not original to him, but were endowed with new epistemological potential, which was his main tool in understanding the functioning and reproduction of the 'social world', as well as in harbouring the energy that moved its engine: power and symbolic capital. These are historical categories inseparable from each other, consistent with the "relational" matrix of the historical agents that sustain them (Vandenberghe, 1999; Fernández, 2013: 35), and have become the true touchstones of his conceptual edifice (Vázquez, 2002; Noya, 2003; Alonso, Martín, Moreno, 2004; Marqués, 2008; Gutiérrez, 2002).

It can be said that the theme itself completes, albeit unintentionally, the general plan of his work. This is achieved not so much through his new conceptual contributions, but by focusing on a "field" that, in his opinion, embraces all the rest and contains the "geometral of all perspectives", to use an image rendered by Leibniz, a philosopher who had considerable influence on Bourdieu's thought, which was also used in other texts to compose a graphic image of the scientificity of knowledge (Zitouni, 2014: 309-317). The State, as emphasised by the editors of the book, is the absent person who nevertheless presides over most of his theoretical and practical research. One could speak of an implicit theme that gives consistency to the fabric of the different spaces of social action, of institutions, in particular schools, and of the mechanisms of symbolic power, to mention only his most wellknown concepts. When discussing "symbolic power", he candidly confessed to his students at the Collège, "I did not know that I was speaking of the state" (Bourdieu, 2012: 288). Similarly, he added, the State was forced on him, without seeking it, when conducting a survey about housing in France (Bourdieu, 2012: 32). In this course the character became present and unveiled the key to that present absence. The State is what enables each of the fields of the social world, and the mechanisms of power established within the institutions, in the justifying and performative discourses of authority, to be connected and understand each other. This is possible precisely because they share the same positions and dispositions, the same linguistic and symbolic codes, because the State constitutes the all-encompassing viewpoint of all viewpoints that are confronted within the individual fields of the social world. At some point, he called it the "central bank" of universally accepted circulating "fiduciary" powers or values which, under those characters of officialdom and universality, are presented with the attributes of "divinity" or "nature", and endows the political activity that founds them with the attributes of a "civil religion". However, it is necessary to bring attention to, and warn against, any attempt to draw from that concept of State any glimpse of "political theology" or transcendental political illusio. For Bourdieu, it is, in any event, a "common historical transcendent" (Bourdieu, 1993a: 59) resulting from the system of structures and social relations, and from cognitive and evaluative dispositions which, taken together, form the social world and its history, sedi- mented from the principles at stake that are involved in its own genetic constitution.

A second circumstantial fact is also highly significant. This is an oral presentation delivered within the context of a highly-specialised course addressed to an audience with very different motivations. This fact, without having any apparent effects on the theoretical conceptions themselves, could have some very interesting analytical potential to understand the impact of Bourdieu's work on history. In the inevitable confrontation between sociology and history that the State as a subject matter involves, the pages on the State contain at least an outline of the burning issues that have been in the European historiographical debate for four decades: the transition from feudalism to capitalism, the question of the 'bourgeois revolution', the meanings of the French revolution, "ideologies" and their authors, the link between culture and social reality, and the confrontation with the great foundations of academic power at the time: philosophical idealism, existentialism, structuralism, and marxism. But throughout the course there is also a very obvious intention on his part to rethink some of the key elements of his work in a pedagogical way, in order to address/clarify the main objections raised against his intellectual endeavour among academic and political-intellectual circles. These include questions such as "invention under structural constraint" (Bourdieu, 2012: 218-221), system of reproduction strategies (Bourdieu, 2012: 374-386) and genetic structuralism. He also sought to illuminate various classic themes in philosophy, anthropology, sociology and history which run adjacent to his main lines of analysis from the perspective of his main methodological instruments.

These questions are thus developed in the direct language of oral communication, far removed from the (difficult) formalisation of written discourse which, as frankly acknowledged by the author, causes difficulties for non-specialists and constituted a permanent concern in his communication with readers (and was also frequently the object of criticism). In addition, this methodical exercise of pedagogy was carried out from the chair of the Collège de France, included among the major academic institutions, although with a very marked vocation of academic innovation: a refuge for the "consecrated heretics" (Bourdieu, 1984: 140-148). This institution was for Bourdieu an "organised fiduciary", a stable mechanism of recognition and legitimation independent of the people who inhabit it (Bourdieu, 2012: 67). It deployed all the capital of authority inherent to it and placed itself at the service of a social scientist who turned the critique of academic institutions into his -arguably- most controversial identity. Such a paradox could not go unnoticed by Bourdieu, a sociologist whose research activity and civic engagement -and ultimately, his own political commitments, especially in his later years- were so strongly engaged in a permanent dialogue between personal circumstances and intellectual reflection.

All this, therefore, means that the transcription of the course is of genuine interest, even if it lacks Bourdieu's direct final authorship. He might have lightened the text 
by deleting some of the digressions and comments about the studies by a very wide range of authors that were woven into the thread of oral discourse, in the style of an open debate between the multiple contributions of anthropology, history and sociology on the subject of the State. In fact, only a minor part of this extensive reflection in the lecture course was systematically developed by Bourdieu subsequently and was finally formulated in written form in the Actes de la recherche en sciences sociales and in later compilations of his writings ${ }^{1}$.

\section{AN EMPIRICAL METHODOLOGY}

Bourdieu firmly laid down a key concept to his study of the State in particular, and of all his work in general from the beginning of the course, which was later repeated in the conclusion, namely a methodology of critical empiricism. It involved resorting to empirical sources and unravelling the often coercive origins of what presumably appears to be most legitimate and universal; and revealing the historical nature of that symbolic order that has been "naturalised" in both things and minds. It is not possible to understand the State, he said, on the basis of the "philosophy of the State", of the State as a representative of order and the common good, because they are ideas provided by the State authority itself. This is knowledge produced by the object of study itself, which generates its own cognitive structures and classification systems through which the social order is "recognised" and integrated by subjects. This ideological universe, Bourdieu thought, on the one hand was installed in an intelligible Olympus (represented on Earth by the SciencePo, Paris), without reference to the social conditions that generated them and to their active agents, and to the realities that, in turn, these incarnate ideas have constructed. On the other hand, it is installed in the head of the social actors, who carry them as second nature and reproduce them by the effect of a key mechanism of social reproduction, such as habitus.

But it is also not possible to know the State by stripping away its transcendent clothing of common good and public order to turn it into a social subject, acting as a representation and instrument of the ruling classes as within the Marxist tradition of the State (from Gramsci to Althusser and Poulantzas), which was very much present in Bourdieu's early years. Although in apparent conflict, this vision shares the aprioristic functional lack of focus that the author deplored in the traditional conceptions of the State, as they merely replaced the "divine State" with the "diabolical State" that underlies the representations of its appropriation by the holders of social power (Bourdieu, 2012: 18).

What can be the idea of the State, then, taking as reference what it does - objectified social facts - and not the functions that have been a priori attributed to it and the ideologies related to them? Let us consider four methodological indicators of Bourdieu's general work, invoked here based on their pertinence to the subject matter, both currently and historically. In the first he referred to the "poet-legislator", the "amusnaw" of Kabilia ethnology (Mammeri, Bourdieu, 1978: 51-66), in which he identified something of the Weberian "ethical prophets" or "legal prophets" in other contexts. These were the characters who say what has to be done in critical situations when the traditional references for the community are lost; those who reconcile the group with the traditional order, with the habitus, even in its inevitable changes and, in so doing, draws from the deepest sources the origin of the official truth, of legitimacy, of symbolic power. There is a large part of this, says the author, in the intervention "ex officio", of the canonical designers of the medieval foundations of modern States.

The second indicator evokes Bourdieu's research on the marital and succession strategies of the peasants of his native Béarn, which was close in time to his studies in Algeria. What began with the primary observation of peasant celibacy and the episode of the singles' dance as a "visible form of the new logic of the matrimonial market" (Bourdieu, 1989: 25), ended up being for the author's pervasive gaze a complex game to put on the table the material structures, the symbolic exchanges and the strategies of reproduction and accommodation of the French peasant world of the time which was in clear decline; and, in relation to the issue of the State now tabled, the empirical-theoretical procedure to understand the reproduction structures and strategies of the big house, the "dynastic State", ${ }^{2}$ based on the individual and the family home.

The third indicator is located in the modern stage of a commission, specifically the 1975 Barre Commission, charged with studying the reform of housing financing in France. ${ }^{3}$ To speak of a commission means to refer to a reality structured by the authority of the State, which at the same time structures a State policy. The commission acts, according to the author, on three levels of meaning: that of "alchemy", which turns the singular (one opinion among many others possible) into the emblem of the official and the public; that of the theatralisation of authority and public discourse, which is enshrined within the official credentials of the commission and its public visibility and provides a decisive element - the symbolic - in all exercise of power, placing it in the field of the moral/universal; and that of the configuration of a particular field of bureaucratic organisation, that is, a form of public action that has historically resulted from the relations between legitimacy, authority, institutions and actors, which have shaped models of management and State structures.

The key players in the fourth indicator are a family group who sought financing to buy a house from an estate agent, under the auspices of a new State policy inspired by the Barre commission. The agent observed, probed, informed, and interacted symbolically with the family and eventually showed himself to be at the same time, in practice, an official of the private (the financing bank), and of the public (which conferred the "right" to benefit from that policy under certain conditions). Again, what appeared to be a situation confined to the realm of private lives was loaded with significance —with collective meaning - which helps to understand the internal social 
genetics that govern the formation and functioning of economic exchanges, and the generating global framework of these practices carried out by the State. ${ }^{4}$

Beyond the specific significance intended by Bourdeau by placing them in his field studies, the four indicators evoked are indicative of his unique approach to social reality, which he applies here to the field of the State, without any major changes. In an academic context dominated at that time by the great theoretical constructions of structuralism and marxism, they meant a return to some particularly fruitful methodological procedures that had been advocated by the founding fathers of sociology. As he pointed out in a text dated from the time when he delivered his course at the Collège, this scientific purpose was to "grasp the deepest logic of the social world" by plunging "into the particularity of an empirical reality, historically located and dated". However, taking up the words of his teacher Gaston Bachelard, -he added- that he considered that empirical reality as a "particular case of the possible", that is, circumscribed and conditioned to the action of the factors at play within a limited universe of feasible configurations (Bourdieu, 1997a [1994]: 12). Bourdieu's remark was more directly related to Max Weber, who had pointed the way in which social science should construct an object of research, and pose problems "with a universal pretension when studying specific cases" (Bourdieu, 1982a: 25). In fact, Bourdieu had followed Weber as an advanced disciple in many of his surveys on subjects that academia had considered trivial.

Regarding Bourdieu's reflections on the State, what he sought through these methodological patterns was, firstly, to show the interaction (the "homologies") between the individual's logics of behaviour, the family home and the dynastic State. In his view, these logics were governed by a principle of corporate continuity that escaped the physically limited duration of their conjunctural representative. This pointed categorically towards how the private has been historically configured and is present in the public, with the family as the first and most universal link in that chain. Secondly, his purpose was to delimit the characteristics of an analytical field capable at the same time of enunciating the logics of singularity and autonomy of the historical subjects, and the logics of universality in their implications for the field of public power, matured in the processes of integration of State resources; a phenomenon that ultimately results in the undisputed legitimacy of the State. And finally, it is worth considering to what extent the differentiated societies nowadays are marked by the State standards of social order, which involves investigating how "the public is present in the private" (Bourdieu, 1997a [1993]: 137).

The academic significance of this methodology indicates a commitment to diving into "the whole field" of the social sciences (Bourdieu 2003b [2001]: 83), including all its sources, and breaking the barriers that separate scientific disciplines and the mental structures that support them. It also involves breaking a vicious circle of "periodic alternation", for academic rather than scientific reasons, of one or the other end of the traditional dualisms that pervade scientific debate: objectivism-subjectivism, individual-society, individualism-holism, historicism-rationalism, structure-action, micro-macro, qualitativequantitative. By accommodating to the conception and history of the State, Bourdieu showed his determination to circumvent some "academic mythologies" linked to the classic studies on the State which in his view are not very effective to understand it fully. Faced with the classic antithesis between the State and civil society, he advocated the relevance of a "continuum" in access to public resources, both material and symbolic, to which the name of State is associated. Faced with the traditional differentiations between nation-state and state-apparatus, with functions assigned a priori to each one, he argued for the reality of a process of constant establishment of material and symbolic apparatuses, which in turn structure frameworks of action, functions and institutions, all of which are the result of a complex struggle between the actors involved. Finally, in the face of the legalistic and administrativist view of the law-State, Bourdieu made a plea to adopt a sequence of bureaucratic rationalisation, as he pointed to the Weberian theoretical domain, or more generally, to an objective historical reason. This was intended in the sense of rules and regularities of social behaviours instituted in things and bodies, capable of forcing instinctive drives and selfish interests in power struggles to be annulled in, and through, regulated conflict, for the benefit of a common enterprise of construction of State rule.

\section{SOCIOLOGY OR HISTORY? GENETIC STRUCTURALISM!}

The course could not but be a new opportunity to settle accounts with the academic boundaries between scientific disciplines, a frequent endeavour in Bourdieu's work. The focus here, logically enough, was history. A very considerable part of knowledge about the processes related to the formation of the State were related to history: that of the accumulation of capital which were linked to the specific field of power or State field, and the creation of its particular rules of the game; the unveiling of the "origins", and the "windows of the possible", that is, of the radical relativism of "historical reason" (which had remained hidden behind the most decisive element for the establishment of the State: symbolic power or violence); and ultimately, that of the singular and paradoxical transmutation of the assets of that playing field between particularity (private opinions and interests), and universality (the transformation of State reason) at the hands of the historical actors of the State. This was the particular "alchemy" that he gave shape to through the borrowed concept of the "mystery of the ministry", 5 again appealing to a concrete empirical analysis: that of representation.

Bourdieu called his particular vision of historical time genetic structuralism: a complex process of permanent construction and transformation of structures based on determining circumstances that are in turn inscribed in the structure and in people's spirit and developed within a 
framework of restricted possibilities (Bourdieu, 2012: 135). Under such a dialectic, he methodologically sought to formulate a problematic "postulate of intelligibility" of the historical processes from their "elemental" mechanisms, in the manner of Durkheim. He did so by bordering, on the one hand, the main shortcomings he observed in academic history and in classical sociology, in particular historical finalism (either metaphysical or rational) (Bourdieu, 2002: 52), sociological functionalism ("social functions are social fictions" endorsed a priori, Bourdieu, 2002: 53), and what he called Bergson's "retrospective illusion" (knowing historical outcomes and simply seeking justifications for them) (Bourdieu, 2012: 217-224). He also tried to establish the principles of a particular enterprise to create the theoretical instruments necessary for scientific practice (an epistemology of the objects of investigation), which was part of sociological reflection from its very origins and Bourdieu considered was lacking in academic history. He believed that this was the true reason for the distancing between history and sociology, otherwise so close due to their object of study.

In the creation of the State, two simultaneous processes were developed through this complex game. The first one was the accumulation of the different capitals that converge in State "banking"; capitals of physical force or coercion, economic capital (taxation), cultural capital, or more descriptively, informational (linguistic, legal, statistical, educational, scientific) capital, symbolic capital (prestige and authority additionally linked to any holder of capital). This is a cumulative process in which it is not difficult to identify the historical theories that have outlined particularly successfully the emergence of modern States (and the names linked to them). Bourdieu analysed three of them most closely: those by Norbert Elias (1982 [1969]), (1988 [1939]) and Charles Tilly (1975), (1992 [1990]), respectively, both linked to two classic ways of accessing legitimate State monopolies (taxation and violence); and that by Philip Corrigan and Derek Sayer (1985), less well-known than the previous two, but especially emphasised by Bourdieu. The reason was the unique analytical alignment between the genesis of the English State proposed by these historians (fundamentally, a cultural revolution that had managed to amalgamate that which is new with a solid heritage), and the proposals of cultural and symbolic legitimacy that the author formulated as the most generally decisive factors in the emergence of modern States (Bourdieu, 2012: 203-216, 224-243). However, strictly speaking, his focus went much further than these models. He analysed numerous other historical works, always emphasising the lines of force that underpinned his proposal. His interest in an oriental country such as Japan was justified precisely by that same interest in culture as a material for the construction of modern nations and States; that is, as a traditional element of both social and political integration, in turn systematically recreated through two State instruments: the school and the army (Bourdieu, 2012: 243-251).

The second process consisted in the formalisation of the particular rules of the game of the State, in which the rules of a social order and an autonomous State reason were beginning to operate in an increasingly complex way (Bourdieu, 2012: 304). Bourdieu organised this process in several phases, which were deployed through the recovery of Roman law by medieval canonists, the development of family logic and strategies of reproduction of the dynastic State, the transition from the State model of family loyalties to another of a bureaucratic type, of formal loyalties and cultural reproduction, and finally, of the transformation of the bureaucratic State into the providential State, where the construction of the State gave way to its relations with the social space. In all these stages, while the characteristics inherent to the State body were created, the individual features of the accumulated capitals were redefined, and a definition was also provided for the actors and spaces of struggle for the appropriation of, and attribution of meaning to, these capitals that were associated with the emergence of the State.

The key to this process resided in the "transmutation" that all those capitals suffered in their genetic course. The relations of force that the historical actors of the State played in the process of their genetic shaping were at the same time relations of "communication and meaning". The game of private interests that it was driven by, while pursuing the monopoly of its assets, inseparably generated a strategy of "objectifying" those interests, in the form of norms and values with presumptions of universality. These would then outline the public, the official, the legitimate, that is, a power that was universally justified by its very existence. Bourdieu calls it symbolic capital or power, a power that developed in its genetic traits the cognitive and evaluative categories of knowledge and recognition that drove the unconditional acceptance of social order. Not so much, therefore, by the direct effect of coercion, but through the unconscious incorporation of common forms of thought, the principles of classification, the instruments, and in general, the construction of social reality into all subjects (Bourdieu, 2012: 266). It is by the use of these that "the State thereby creates the conditions of an immediate orchestration of habitus that is itself the foundation of a consensus on this set of shared self-evidences constitutive of common sense", the "ordinary order of things" (Bourdieu, 2003a [1997]: 252-253).

Adopting the differentiation made in The Elementary Forms of the Religious Life by the father of French sociology, Durkheim (very present throughout Bourdieu's course), the State would thus be the foundation of "logical integration" (consistency on the same categories of thought, of perception, of construction of reality) and of "moral integration" (agreement on a certain number of values) of the social world (Bourdieu, 2012: 15, 266).

Symbolic power is, in his opinion, the most genuine form of State power. It is a hidden type of power, transmuted into charisma, a power that does not have to be exercised as coercion, because it is embedded in things, bodies and minds, and exercised with the acquiescence of those who suffer it. It is also a disposition incorporated through a systematic process of socialisation (initially in the domestic realm, but above all in school), the most 
powerful instrument for the transmission of codes, norms, values and divisions of the social world; an imposition that ultimately relies on the "unconscious harmony between objective structures and mental structures" (Bourdieu, 2012: 239). Perhaps, as Loïc Wacquant said, the main purpose of Bourdieu's work from the beginning, as well as its greatest strength was: "to explicate the specificity and potency of symbolic power, that is, the capacity that systems of meaning and signification have of shielding, and thereby strengthening, relations of oppression and exploitation by hiding them under the cloak of nature, benevolence and meritocracy" (Wacquant, 2005: 160).

Pierre Bourdieu liked to repeat that all the potency of the State could be summed humorously: the State is the capacity, first, to protect perfectly arbitrary objective elements, although certainly not lacking in coherence and systematicity, such as spelling rules, with their grammars and their dictionaries; second, to support a group of faithful devotees whose social life and professional interest are involved in the management of these norms and to do it as if they were revealed truths or impositions of nature; and, finally, to generate an unshakable fidelity towards them in people willing to die for spelling (Bourdieu, 2012: 194). A very French joke, only exaggerated in appearance, considering how much energy the French expend when there are any attempts to change their devilish spelling system.

\section{THE CONSTRUCTION OF THE STATE, THE CONSTRUCTION OF HIMSELF}

The process described can therefore be understood as a procedure of systematic subjectivation of the normative contents of the State, but also as another parallel of the incorporation of the subjective into the State object. In the wake of what Max Weber had pointed out for the religious field - the need to complete the study of its symbolic configurations with that of its creative agents (Bourdieu, 1971) - Bourdieu had great interest in highlighting the epistemological status that corresponded to the world of the private interests of historical actors and the phenomenon, only apparently antithetical, of the shaping of "disinterestedness", the official, the public, the universal that is conventionally related to the properties of the State. And closely related to this objective is another one linked to the performative efficiency of the discourses of authority through which the construction of legitimate reality is enshrined (Bourdieu, 1975: 183-190). This is only a particular aspect of a constant reflection on language throughout his academic career, namely language as another fundamental component of social determination, of social fractures inscribed in the habitus and of the determinants of scientific practice, which he finally encompassed in the concept of the "economy of language exchanges" 7 .

"Corporatism of the universal" was the phrase Pierre Bourdieu used to describe that singular economy of symbolic goods in the field of artistic creation, where the mis- understandings between the supposed (idealist) autonomy of universal values (purportedly materialised in culture) and the particular (materialist) interests and constraints of the agents who emitted the message were archetypically shaped. A field of analysis that he wanted to rethink, avoiding the determinist approaches (whether they be structuralist or rational) prevailing in the cultural studies of the time, and particularly in the field of intellectuals, so present in the academic debate throughout the period of his education and research career (Bourdieu, 1992: 461472).

Bourdieu applied the same concept to the subject of the State analysed here with full appropriateness. What he intended to emphasise was that the process of public management is inseparable from the process of the constitution of various categories of agents (nobility of the State, jurists, linguists, administrators, statisticians and other experts involved in the primary management of the State). These are characterised by creating and appropriating the universal and its resources, constituting a whole world of State agents who have constructed the State's discourse. They have had a certain interest in giving a universal form to the particular expression of their interests, through which they have accessed a theory of public service and, by producing an "ideology" justifying their position and the struggles waged to preserve and strengthen it, have objectified the universal categories of the State, State thought and operating rules (Bourdieu, 2012: 278).

Through the complex game in which individuals, positions, generative representations of collective identities and linguistic or technical capacities are interwoven, the actions of these constructors of the State succeed in underpinning the State's legitimacy and, at the same time, in placing it in progressively depersonalised and universal logics in the very process of defining it ideologically (the crown, law, public order, the national language, State taxation) and establishing the legitimacy of its appropriation as the sole legitimate instance.

\section{THE 'SOCIOLOGISED' SOCIOLOGIST}

How can these rules of the game of the subjectivised State and objectified interests not be applied when one forms part of and speaks from a State institution, when one takes the word of authority, as in ancient times, with a ritual of rigour, and when so many features of his scientific enterprise, recognised by himself, resulted from the "socially constituted dispositions" (Bourdieu, 2003b [2001]: 187) of his origin and of his academic and professional career?

To return to the start for a moment, here is a wellknown but controversial sociologist, occupying the chair of a prestigious French educational institution, who engages in an "institutional act" that could be interpreted, despite himself, as an act of "scholastic" authority. This is ultimately an act of State. An additional motive for reflection, in other words, for applying once again that general principle of critical reflexivity or "socio-analysis" charac- 
teristic of all his work, to the author's constraints in his relations with his object of study and his work (epistemological reflection) and in his ethical commitments to the political and social issues of his time. Again, the specific circumstance of the academic act taking place here had the potential of incorporating the past and the specific constraints of its realisation. "Every discourse -he noted in connection with these academic rituals- owes a certain number of its properties to the circumstances in which it was pronounced" (Bourdieu, 2012: 500).

These suggestions undoubtedly led him to reflect on the unique position in which he was placed by circumstances on the occasion of his first lesson given years before at the Collège. "Lessons on the lesson" was the title and was, first of all, a somewhat hesitant and critical proclamation of this personal journey, although -he would say later- it was an essential attitude to "make the experience bearable" (Bourdieu, 2003b [2001]: 190). But then it was a candid explanation of the objective dilemmas that this circumstance posed to his sociological enterprise: how to give scientific value to a reflection doubly conditioned by an individual habitus and by an "institutional act". In fact, the weight of that basic epistemological position (the relationship of the subject to the object of study, the fact that the subject constantly records as a fact what are nothing more than value judgments) (Bourdieu and Chartier, 2010: 35) was undoubtedly decisive for his own intellectual reflection from his earliest empirical investigations into the Algerian Kabylia. It continued to be present in his permanent search for the unique status of sociological knowledge, which constantly involved the social world and its history and the subject itself which produced it intellectually; and which of course critically interpellated its academic environment, which was still much more problematic. These concerns became increasingly intense over the years, as he saw the need to unite the epistemological imperatives of his professional endeavour consistently with the increasingly strong demands of his ethical and political commitments (Rodríguez, 2002). It was not, therefore, random that his last lessons in the Collège, after the course on the State, were devoted to provide continuity to the questions raised in that first lecture. Using his own words, its objective was once again to elucidate under what conditions and methods it was possible to construct a "scientific truth capable of integrating the observer's vision and the truth of the practical vision of the agent as a point of view which is unaware of being a point of view and is experienced in the illusion of absoluteness" (Bourdieu, 2003b [2001]: 198). In this light, the fact that, following that mentioned course at the Collège, his last published work was dedicated precisely to locating his own intellectual journey in the academic context of his formative stage and of his research career had a high symbolic value ${ }^{8}$. As if, perhaps to his regret, he had seen that some of the key concepts of his own intellectual adventure might be hidden there. This same demand was found in the first final conclusion of his study of the State: constructing the history of the genesis of the state was to "construct the history of our own thinking", our habitus relative to the State (Bourdieu, 2012: 538). Something that ultimately meant emphasising that reflexive enterprise of objectifying the "objectifier" as a first-order "disposition" of the subject to think epistemologically about the given discipline in a new way, and to face the challenges of the surrounding world from an ethical perspective. In sum, he intended to approach a realistic policy (Realpolitik) of reason that included an ethical commitment directly linked to the specific objects of scientific knowledge, in the manner of a "rational utopianism", based on "the knowledge of the probable to make the possible come true" (Bourdieu, Wacquant, 2005 [1992]: 278).

\section{A GENETIC HISTORY OR SOCIOLOGY OF THE STATE?}

Does this "disposition" adequately meet the two challenges proposed? Does the Bourdieuian sociology of the State represent, therefore, an important interpretative instrument of the already extensive corpus of historical studies concerning the State, and an accurate judgment of its consideration in the present time as the key player in public life? In other words, does the sociology of Pierre Bourdieu provide some tools of particular interest to the ordinary work of the classical historian in this and other subjects, and to address the issues that engage the social science scholar as a citizen of the social world, a world supposedly embedded in the State's footprint?

Academic disputes aside, the fact that there are numerous historians who are disciples of Bourdieu, and that he attentively — but also critically - watched the relations between genetic structuralism and history, suggests that there might be some methodological affinity between the two disciplines. This may have been shown in at least two general reflections in his dialogue with the historians Lutz Raphael and Roger Chartier (Bourdieu, 1995 and Bourdieu and Chartier, 2010). Indeed, some old names, some old historiographical polemics, which were emblems of a whole generation of historians of the 1970s and 1980s, appear in the pages of this text, as ghosts of a past time. The subsequent scientific dissipation of some of these disputes provided a basis for Bourdieu's opinion that these were false historical problems, useful only for confronting the weight of academic powers and for fuelling the struggles on which scientific fads are usually grounded. However, despite the interest and penetration of many of his approaches, it cannot be said that all the interpellations to the traditional culture of the State are illuminated with the same clarity. His voice is sometimes hesitant, the historical assets that feed his emergency categories of the State are partial, restricted to those properties consistent with the key concepts of his sociological theory. Sometimes his analyses are presented in the form of programmatic proposals rather than as true results of historical or sociological research.

A $\log$ of historical themes and commentary of permanently suggestive readings, the lessons from the course are particularly appealing to historians. There is, above 
all, an aspect that links the work of Bourdieu as a whole, not only that on the State, to the ordinary modus operandi of the historian. The categories of Bourdieu's sociology, as has often been argued against certain summary critiques, have an open configuration. The "fields" in which battles of relations and meaning fought by social actors are constructed and redefined in each case in relation to the relevant empirical realities. They are not different from the way in which the historian demarcates the relevant properties to the object of study. Historical reason is recomposed in each field in the internal struggle between structure and habitus, and is therefore not conformed as a result of closed formulations. Alongside academic reasoning and the compartmentalisation of social disciplines, Bourdieu's usual reproach to the academic work of his time was sociologism, that is, the propensity to turn the trends and regularities of social phenomena into immovable laws. Whereas his basic categories were already formed between the 1960s and 1970s, he never stopped examining them in his subsequent editorial projects. So his works are full of redefinitions, patterns and metaphors, constantly renewed, about what he understood by "field", habitus and symbolic power. They are open propositions that his critics and commentators have often tried to unravel, and in many other cases to contest.

Still, the fact remains that these sociological categories are extracted from the analysis of the contemporary social world. Bourdieu himself was aware that his transposition of history to the genetic territory was possible only on the basis of a "philosophical" hypothesis, which in the present analysis of the State was expressed as follows: "The philosophy of history I shall apply in my further analysis is that at each moment the whole of history is present in the objectivity of the social world and in the subjectivity of the social agents that make further history" (Bourdieu, 2012: 135). In a broad sense, this is still a general characterisation of the trans-historical and universal result that he considered to be produced in all scientific knowledge based on a historical activity, circumscribed to a time and a space, as proposed in his latest analyses on science (Bourdieu, 2003b [2001]): 12).

Can it be said that this trans-historical operation is thoroughly fulfilled in its sociological and historical considerations on the State? To a great extent, it is, although with some reservations. As some commentators have remarked regarding another key work of his theoreticalpractical corpus (The Distinction), in this work his theory of domination and legitimacy, the core of his conception of the social world, pre-exist any empirical or historical foundations, and constitute the only interpretative framework of the data provided by research in these areas ( $\mathrm{Fa}-$ biani, 2016: 156). In fact, behind the abundant references he gathered from historical research on the State, his essential intention lies in proving, firstly, that this "field of fields" could be applied to the general categories to approach the social world that he had developed through his empirical research on contemporary reality; and secondly, that the ultimate key aspect to the legitimacy of the State lies in the mechanism of denial of the political and eco- nomic instances of force (be they called power / domination / coercion / violence) that the state represents at the highest level for the benefit of its legitimate and universal acceptance as symbolic power / violence (Dubois, Durand, Winkin, 2013; Fernández, 2005: 25-26).

Thus, his discourse does not cease to generate some misunderstandings directly derived from these bases, manifested both in the plane of his conceptions of the historical State and of his practical positions with regard to the form of the state of his time. A first problem concerns the concepts of power and violence, especially the latter, which are inseparably attached to symbolic adjectivation. It seems clear that such use is removed from the ordinary value of use of the concept. Giving to the sociologist his own sociological medicine, one could say that it seems to result, rather, from the false vehemence with which this type of gross disqualification is used -"intellectual terrorism" would be another- in the intellectual and academic struggles of the French cultural world. One could even take for granted the equivalence between repression and power, although it is masked here in the form of symbolic domination. Bourdieu seems to pay tribute, albeit a critical one, to Michel Foucault's positions on the coercive character of all power, on its capacity for generating the real and its genesis in the conflictive relationship of historical actors, rather than on a priori contractualist or economistic type conceptions. But this would always be a type of repression / violence denied by its actors, whose disclosure would destroy all its force (Dubois, Durand, Winkin, 2013: 5). If the key to the emergence of the State is symbolic violence, the acceptance of the arbitrary and coercive presuppositions encountered at the origin of social normativity in the form of doxa, history (with its specific factual methodology) could hardly find a safe anchor for trans-historical rationality unless resort is made to a remote and indeterminate origin, a time and a form in which power or violence are simply coercion or physical violence; or unless, outside of the historical discipline, one resorts to a religious, philosophical or psychoanalytic founding myth, which inaugurates the historical time of a social order and a culture. Foucault at least adopted war (and the imbalance of forces generated in it) as a primordial fact of the power and structures of State domination, guided by the important historical instances that had proven it to be the determining factor in the birth of modern states (Foucault, 2001 [1997]). Instead, Bourdieu wanted to focus on what he regarded as his main contribution to the genesis of the State: culture and the symbolic relation structures, above war, violence and taxation. This has enabled some scholars to say that his State model was too embedded in the anthropological formulas of cultural relation linked to the symbology with which wealth, position, status or cultural level is manifested (from the ex officio to the 'family', from family loyalty to bureaucracy), and insufficiently connected to the models of appropriation of resources that denote relations of production in the Marxist tradition (Fabiani, 2016: 23). This is what ultimately gives consistency to the symbolic order of relations between historical actors. 
By faking such relations by concealing them under formulas of symbolic coercion or violence, Bourdieu, to his regret, introduced a second misunderstanding, in this case about what the State has become in the world today. This bias has blurred the historical rational disposition (the concentration and universalisation of state capitals) that in each historical stage has been fulfilled to the detriment of the particular interests and opinions of the historical agents of the State. In the present State form, this totalising asset is represented by the Welfare State, which constitutes a collective programme of the social order entrusted to the body of the State, a programme largely indebted, in Bourdieu's opinion, to the scientific contributions of the modern social sciences (Bourdieu, 2012: $575)$. On the basis of such a dialectic, it has been said that Bourdieu started out with a critique of intellectualism (as Marx did) and ended up (as Hegel did) mobilising under the banner of an internationale of intellectuals or under of the universality of the State (Burawoy, 2008: 11). It may not be necessary to go that far. However, it is possible to glimpse an end of history in its State itinerary (or at least a pause to it), as if all the potentialities of that State had not been exhausted in the present world (of course, in the Eurocentric and French world, which is the one of his fundamental perspectives of analysis) (Scott, 2013). Or at least the possibilities of the "left-hand State" as it has now begun to be differentiated, no doubt to separate it from the historic coercive imprint. As early as 1989-1990, the course aimed to unravel some perplexities that soon would be a constant cause of uneasiness for him as a man of science interested in the destiny of the men of his time; the Bourdieu of the survey on world poverty and the Contre-feux faced with the neo-liberal invasion (Bourdieu, 1993b, 1998, 2001b), that of the excited words spoken to trade unionists and to the railway workers on strike (Fabiani, 2016: 215-243). The State that constructs realities and doxic submissions appears there as a value built on the potentialities of human achievement, especially since the eighteenth century. It is this State that is now being dismantled, the State challenged by some privileged sectors as a strategy, in their words, to have everything (the benefits of liberalism, the benefits of freedom, the benefits of state dependence) and not pay anything for it; the State, ultimately whose space is being occupied, in its retreat, by religion, individualism and other myths (Bourdieu, 2012: 481, 583-584).

\section{NOTES}

1 Specifically, these were Bourdieu, 1993a, Bourdieu, 1997b and Bourdieu, 2001a. He had previously published another text closely related to these ones, Bourdieu, 1986: 3-19.

2 The surveys on marriage strategies conducted between 19591960 and 1970-1971 resulted in three studies published between 1962 and 1989, Bourdieu, 1962, Bourdieu, 1972, Bourdieu, 1989, compiled under the title le Bal des célibataires, 2002. In its preliminary pages he summarised the path that had led him from the phenomenology of affective life to an objective view of the peasant social world.

3 The Study Commission on a reform of housing financing, set up by the French Council of Ministers on 22 January 1975.
4 The work of this commission was analysed in Bourdieu, Pierre, Christin, Rosine, 1990: 65-85 (Bourdieu, 2000).

5 Collected from one of his most precious sources on the subject of the State for reasons of methodological affinity, the German historian Ernst Kantorowicz (Bourdieu, 2001a: 7-11).

6 The most emblematic works by these authors to which Bourdieu refers were Elias, 1982 [1969], and the second part of Elias, 1988 [1939], Tilly, 1975, Tilly, 1992 [1990] and Corrigan, Sayer, 1985.

7 Various publications on the subject are collected together in in Bourdieu, 1982b and Bourdieu, 1987.

8 This was first published in German under the title Ein Soziologischer Selbstversuch. Suhrkamp, Frankfurt am Main, 2002. The French edition was published only two years later, Bourdieu, 2004.

\section{REFERENCES}

Alonso, Luis Enrique, Martín Criado, Enrique, Moreno Pestaña, José Luis (2004) Pierre Bourdieu, las herramientas del sociólogo. Fundamentos, Madrid.

Bourdieu, Pierre (1962) "Célibat et condition paysanne". Études rurales, 5-6: 32-135.

Bourdieu, Pierre (1971) "Genèse et structure du champ religieux". Revue française de sociologie, 12 (3): 295-334.

Bourdieu, Pierre (1972) "Les stratégies matrimoniales dans le système de reproduction". Annales, Économies, Sociétés, Civilisations, 27e année, 4-5: 1105-1127.

Bourdieu Pierre (1975) "Le langage autorisé. Note sur les conditions sociales de l'efficacité du discours rituel". Actes de la recherche en sciences sociales, 5-6, novembre: 183-190.

Bourdieu, Pierre (1982a) "N'ayez pas peur de Max Weber". Libération, 6 juillet: 25 .

Bourdieu, Pierre (1982b) Ce que parler veut dire. L'économie des échanges linguistiques. Fayard, Paris.

Bourdieu, Pierre (1984) Homo academicus. Minuit, Paris.

Bourdieu, Pierre (1986) "La force du droit. Eléments pour une sociologie du champ juridique". Actes de la recherche en sciences sociales, 64, septembre: $3-19$.

Bourdieu, Pierre (1987) Choses dites. Minuit, Paris

Bourdieu, Pierre (1989) "Reproduction interdite. La dimension symbolique de la domination économique". Études rurales, 113-114: 15-36.

Bourdieu, Pierre (1992) Les règles de l'art. Genèse et structure du cham littéraire. Seuil. Paris

Bourdieu, Pierre (1993a) "Esprits d'État. Genèse et structure du champ bureaucratique". Actes de la recherche en sciences sociales, 96-97, mars: 49-62.

Bourdieu, Pierre (1993b) La misère du monde. Seuil, Paris

Bourdieu, Pierre (1995) "Sur les rapports entre la sociologie et l'histoire en Allemagne et en France. Entretien avec Lutz Raphael". Actes de la recherche en sciences sociales, 106-107, mars 1995: 108-122.

Bourdieu, Pierre (1997a [1993] "El espíritu de familia”. In Razones prácticas. Sobre la teoría de la acción. Anagrama, Barcelona: 126-138.

Bourdieu, Pierre (1997a [1994]) "Espacio social y espacio simbólico". In Razones prácticas. Sobre la teoría de la acción. Anagrama, Barcelona: 11-26.

Bourdieu, Pierre (1997b) “De la maison du roi à la raison d'État. Un modèle de la genèse du champ bureaucratique". Actes de la recherche en sciences sociales, 118, juin: 55-68.

Bourdieu, Pierre (1998) Contre-feux: propos pour servir à la résistance contre l'invasion néo-libérale. Liber-Raison d'Agir, Paris.

Bourdieu, Pierre (2000) Les structures sociales de l'économie. Seuil, Paris

Bourdieu, Pierre (2001a) "Le mystère du ministère. Des volontés particulières à la "volonté générale"". Actes de la recherche en sciences sociales, 140, décembre: 7-11.

Bourdieu, Pierre (2001b) Contre-feux: pour un mouvement social européen. Raison d'Agir, Paris. 
Bourdieu, Pierre (2002) Le Bal des célibataires. Crise de la société paysanne en Béarn. Seuil, Paris.

Bourdieu, Pierre (2003a [1997]) Méditations pascaliennes. Seuil, Paris.

Bourdieu, Pierre (2003b [2001]) El oficio de científico. Ciencia de la ciencia y reflexividad. Curso en el Collège de France 20002001. Anagrama, Barcelona.

Bourdieu, Pierre (2004) Esquisse pour une auto-analyse. Raison d'Agir, Paris.

Bourdieu, Pierre (2012) Sur l'État. Cours au Collège de France (1989-1992), edited by Champagne, Patrick; Lenoir, remi; Popupeau, Franck; Riviere, Marie-Cristine. Raisons d'Agir/Seuil, Paris.

Bourdieu, Pierre, Christin, Rosine (1990) "La construction du marché. Le champ administratif et la production de la 'politique du logement"'. Actes de la recherche en sciences sociales, 81-82, mars: 65-85.

Bourdieu, Pierre, Wacquant, Loïc (2005 [1992]) Una invitación a la sociología reflexiva. Siglo XXI editores, Buenos Aires.

Bourdieu, Pierre, Chartier, Roger (2010) Le sociologue et l'historien. Agone/Raison d'Agir, Marseille.

Burawoy, Michael (2008) "Conversations with Pierre Bourdieu. The Johannesburg Moment, 2 Theory and Practice: Marx meets Bourdieu" http://burawoy.berkeley.edu/Bourdieu/3.Marx.pdf (accessed 20/02/2017).

Corrigan, Philip, Sayer, Derek (1985) The Great Arch. English State Formation as Cultural Revolution. Blackwell, Oxford-New York.

Dubois, Jacques, Durand, Pascal, Winkin, Yves (2013) “Aspects du symbolique dans la sociologie de Pierre Bourdieu. Formation et transformation d'un concept générateur". COnTEXTES. Revue de sociologie de la littérature, https://contextes.revues.org/5661 (accessed 20/02/2017).

Elias, Norbert (1982 [1969]) La sociedad cortesana. FCE, México.

Elias, Norbert (1988 [1939]) El proceso de la civilización. Investigaciones sociogenéticas y psicogenéticas. FCE, México.

Fabiani, Jean-Louis (2016) Pierre Bourdieu. Un structuralisme hérö̈que. Seuil, Paris.

Fernández Fernández, José Manuel (2005) "La noción de violencia simbólica en la obra de Pierre Bourdieu: una aproximación crítica". Cuadernos de Trabajo Social, 18:7-31.
Fernández Fernández, José Manuel (2013) “Capital simbólico, dominación y legitimidad. Las raíces weberianas de la sociología de Pierre Bourdieu". Papers, 98 (1): 33-60.

Foucault, Michel (2001 [1997]) Defender la Sociedad. Curso en el Collège de France (1975-1976). Edición establecida bajo la dirección de Ewald, François y Fontana, Alessandro por Bertani, Mauro y Fontana, Alessandro en el marco de la Association pour le Centre Michel Foucault. FCE, México.

Gutiérrez, Alicia B. (2002) Las prácticas sociales: una introducción a Pierre Bourdieu. Tierradenadie, Madrid.

Lenoir, Rémi (2012) "L'État selon Pierre Bourdieu". Sociétés contemporaines, 87 (3): 123-154.

Mammeri, Mouloud, Bourdieu, Pierre (1978) "Dialogue sur la poésie orale de Kabylie". Actas de la recherche en sciences sociales, 23, septembre: 51-66.

Marqués Perales, Ildefonso (2008) Génesis de la teoría social de Pierre Bourdieu. CIS, Madrid.

Noya, Francisco Javier (Ed.) (2003) Cultura, desigualdad y reflexividad. La sociología de Pierre Bourdieu. La Catarata, Madrid.

Rodríguez, Joaquín (2002) Pierre Bourdieu. Sociología y subversión. La Piqueta, Madrid.

Scott, Alan (2013) "We are the State. Pierre Bourdieu on the State and Political Field". Rivista di Storia delle Idee, 2 (1): 65-70.

Tilly, Charles (dir.) (1975) The Formation of National States in Western Europe. Princeton University Press, Princeton.

Tilly, Charles (1992 [1990]) Coerción, capital y los Estados Europeos, 990-1990. Alianza, Madrid.

Vandenberghe, Frédéric (1999) "The Real is Relational: An Epistemological Analysis of Pierre Bourdieu's Generative Structuralism”. Sociological Theory, 17 (1) March: 32-67.

Vázquez García, Francisco (2002) Pierre Bourdieu. La sociología como crítica de la razón. Montesinos, Barcelona.

Wacquant, Loïc (2005) "Tras las huellas del poder simbólico. La disección de la "nobleza de Estado"'. In El misterio del ministerio. Pierre Bourdieu y la política democrática, edited by Wacquant, Loïc. Gedisa, Barcelona: 159-177.

Zitouni, Benedikte (2014) "Petites perceptions et trajets de classe: le rapport de Bourdieu à Leibniz". In Le sociologue comme médiateur? Accords, désaccords et malentendus. Hommage à Luc Van Campenhoudt, sous la direction de Jean-Pierre Delchambre, Université Saint-Louis, Bruxelles: 309-317. 